\title{
THE WORKING LIFE OF A GROUP OF NURSES
}

\section{B.N. HUNT}

\section{OPSOMMING}

Hier word 'n oorsig gegee van die loopbane van die 139 geregistreerdeverpleegkundiges wat'n B.Soc.Sc. (Verpleegkunde) - graad aan die Universiteit van Natal behaal het. Van die potensiële 981 werkjare wat hierdie gegradueerdes sou kon gewerk het, is 551 jaar $(56,2 \%)$ met verpleegwerk deurgebring, gedurende $372(37,9 \%)$ jaar is daar nie gewerk nie en 58 $(9,5 \%)$ jaar is op terreine buite verpleging deurgebring.

\section{INTRODUCTION}

A B. Soc. Sc. (Nursing) course has been offered since 1962 at the University of Natal, Durban. This is a four-year course, on successful completion of which students are eligible for registration as general nurses and midwives with the South African Nursing Council.

In spite of the fact that undergraduate nursing courses are now well-established at almost all South African universities, remarkably little information is available on the working-life and career pattern of the graduate nurse in South Africa. It is still common for members of the public to express surprise that students can obtain nursing qualifications through university-based pro grammes. Furthermore, surprise is again expressed that such students should continue in a nursing career on successful completion of a nursing degree.

For these reasons, it is of interest to review the careers of students who have passed through the University of Natal programme during the period 1962-77. The necessary information has been gathered over the years through frequent personal contact by members of staff of this department with their ex-students. The number of graduates is presently small enough for this to be possible.

Table 1 gives relevant information regarding student intake.

Over the sixteen year period, there has been a total intake of 270 students, of whom $151(55,9 \%)$ have been successful in obtaining the B.Soc. Sc. (Nursing) degree. The major reason for withdrawal from the degree programme is failure of examinations in the first year. It is of great interest that 62 of the 119 students who withdrew from the university-based nursing course transferred to a hospital-based

\begin{tabular}{|c|c|c|c|c|c|c|c|}
\hline \multicolumn{8}{|c|}{$\begin{array}{c}\text { TABLE } 1 \text { NUMBER OF STUDENTS WHO BECAME } \\
\text { REGISTERED NURSES }\end{array}$} \\
\hline \multirow[t]{2}{*}{$\begin{array}{l}\text { Year of } \\
\text { student } \\
\text { In take }\end{array}$} & \multirow[t]{2}{*}{$\begin{array}{l}\text { Total } \\
\text { student } \\
\text { intoke }\end{array}$} & \multicolumn{2}{|c|}{$\begin{array}{l}\text { Persans who completed } \\
\text { University } \\
\text { Nursing degree course }\end{array}$} & \multicolumn{2}{|c|}{$\begin{array}{l}\text { Persons who transferred } \\
\text { to Diploma } \\
\text { Nursing course }\end{array}$} & \multicolumn{2}{|c|}{$\begin{array}{l}\text { Persons wasted } \\
\text { to Nursing }\end{array}$} \\
\hline & & Number & Percentage & Number & Percentage & Number & Pereentage \\
\hline 1962 & 10 & 6 & $(60,0)$ & 1 & (10) & 3 & $(30,0)$ \\
\hline 1963 & 8 & 5 & $(62,5)$ & 1 & $(12,5)$ & 2 & $(25,0)$ \\
\hline 1964 & 11 & 4 & $(36,3)$ & 2 & $(18,2)$ & 5 & $(45.5)$ \\
\hline 1965 & 12 & 9 & $(75,0)$ & 2 & $(16,7)$ & 1 & $(8,3)$ \\
\hline 1966 & 8 & 6 & $(75,0)$ & 1 & $(12,5)$ & 1 & $(12,5)$ \\
\hline 1967 & 15 & 8 & $(46,6)$ & 3 & $(20,0)$ & 4 & $(26,7)$ \\
\hline 1968 & 13 & 10 & $(76,9)$ & 3 & $(23,1)$ & 0 & $(0,0)$ \\
\hline 1969 & 11 & 6 & $(54,9)$ & 2 & $(18,2)$ & 3 & $(27,3)$ \\
\hline 1970 & 25 & 16 & $(64,4)$ & 3 & $(12,0)$ & 6 & $(24,0)$ \\
\hline 1971 & 32 & 20 & $(62,5)$ & 6 & $(18,8)$ & 6 & $(18.8)$ \\
\hline 1972 & 20 & 9 & $(45,0)$ & 6 & $(30,0)$ & 5 & $(25,0)$ \\
\hline 1973 & 19 & 10 & $(52,6)$ & 5 & $(26,3)$ & 4 & $(21,1)$ \\
\hline 1974 & 21 & 8 & $(38,0)$ & 10 & $(47,6)$ & 3 & $(14,3)$ \\
\hline 1975 & 23 & 14 & $(50,8)$ & 3 & $(13,0)$ & 6 & $(26,1)$ \\
\hline 1976 & 19 & 8 & $(42,1)$ & 7 & $(36,8)$ & 4 & $(21,1)$ \\
\hline 1977 & 23 & 12 & $(52,1)$ & 7 & $(30,4)$ & 4 & $(17,4)$ \\
\hline TOTAL & 270 & 151 & $(55,9)$ & 62 & $(22,9)$ & 57 & $(21,1)$ \\
\hline
\end{tabular}

Diploma in Nursing course and subsequently achieved registration as nurses by this route.

Of the total student intake of 270 into the B. Soc. Sc. (Nursing) course therefore, $78,9 \%$ of the girls became registered nurses by one or another means. This is a surprisingly low wastage rate in comparison to British studies of student nurse wastage. ${ }^{1}$

\section{CAREERS AFTER}

GRADUATION

In sixteen years, what has become of the 151 students who were successful in obtaining a B. Soc. Sc. (Nursing) degree?

A partragal of the working lives of these nurses is given in Table 2. Of the 139 graduates, $102(73,4 \%)$ are married and $64,7 \%$ of these young

\begin{tabular}{|c|c|c|c|c|c|}
\hline \multicolumn{6}{|c|}{$\begin{array}{l}\text { TABLE } 2 \text { WORKING LIFE OF NURSES WHO COMPLETED } \\
\text { B. SOC. SC. (NURSING) COURSE }\end{array}$} \\
\hline $\begin{array}{l}\text { YEAR OF } \\
\text { INTAKE }\end{array}$ & $\begin{array}{l}\text { NUMBER OF } \\
\text { NURSING } \\
\text { GRADUATES }\end{array}$ & $\begin{array}{l}\text { NUMRER } \\
\text { WHO ARE } \\
\text { MARRIED }\end{array}$ & $\begin{array}{c}\text { NUMBER } \\
\text { WORKING } \\
\text { WITHIN } \\
\text { NURSING ON } \\
31.12 .80\end{array}$ & $\begin{array}{c}\text { NUMBER } \\
\text { WORKING } \\
\text { OUTSIDE } \\
\text { NURSING ON } \\
31.12 .80\end{array}$ & $\begin{array}{l}\text { NUMBER NOT } \\
\text { WORKING ON } \\
13.12 .80\end{array}$ \\
\hline 1962 & 6 & 4 & 2 & 1 & 3 \\
\hline 1963 & 5 & 4 & 1 & - & 4 \\
\hline 1964 & 4 & 4 & - & 1 & 3 \\
\hline 1965 & 9 & 8 & 1 & 3 & 5 \\
\hline 1966 & 6 & 6 & 5 & - & 1 \\
\hline 1967 & 8 & 8 & 1 & - & 7 \\
\hline 1968 & 10 & 9 & 6 & 1 & 3 \\
\hline 1969 & 6 & 6 & 1 & - & 5 \\
\hline 1970 & 16 & 12 & 7 & 1 & 8 \\
\hline 1971 & 20 & 14 & 6 & 3 & 11 \\
\hline 1972 & 9 & 6 & 6 & 1 & 2 \\
\hline 1973 & 10 & 4 & 7 & 2 & 1 \\
\hline 1974 & 8 & 4 & 5 & 1 & 2 \\
\hline 1975 & 14 & 10 & 10 & 2 & 2 \\
\hline 1976 & 8 & 3 & 5 & 1 & 2 \\
\hline TOTAL & 139 & 102 & 63 & 17 & 59 \\
\hline
\end{tabular}


married women have children, both of which are circumstances likely to interrupt the working-life of the nurse in particular. At the end of December $1980,63(45,3 \%)$ of the nursing graduates were working as nurses (twelve were working outside South Africa), $59(42,4 \%)$ were not working and $17(12,2 \%)$ were not working as nurses.

Reference to Table 3 indicates the actual amount of time in years that the nurses have worked.

Between them, the 139 graduate nurses could potentially have worked, a total of 981 years had there been no interruptions. In fact, a total of 609 years has been worked, $62,07 \%$ of the total possible number of working years. This work record is gratifying in view of the fact that the young women in question are representatives of an affluent White society, much given (if not marrying during their student years or immediately after completion of their degree) to travel and trying their wings in all sorts of directions.

THE TYPE OF WORK UNDERTAKEN AFTER GRADUATION

An important factor is the manner in which the 609 working-years have been occupied. Nursing work has filled 551 working-years $(90,6 \%$ of total time worked); work outside nursing accounts for 58 workingyears $(9,5 \%$ of total years worked). Reference to Table 4 shows the careers followed by the seventeen graduates who were employed outside nursing on 31 December 1980.

Sixty-three $(45,3 \%)$ of the total number of graduates were employed within nursing on the same date. Table 5 accounts for the nursing fields in which they were occupied.

\section{POST-GRADUATE QUALIFICATIONS}

The number of post-graduate qualifications obtained by a relatively small group of nurses would seem to denote, at least, a great deal of hard work and motivation. Since obtaining their basic degree, $65(46,7 \%)$ of the 139 graduates have successfully completed some form of study related to nursing.

Table 6 shows the professional qualifications obtained by the graduates and Table 7 the academic qualifications obtained. It must be

\begin{tabular}{|c|c|c|c|c|c|c|}
\hline $\begin{array}{l}\text { YEAR OF } \\
\text { INTAKE } \\
\text { INTO } \\
\text { COURSE }\end{array}$ & $\begin{array}{l}\text { NUMBER OF } \\
\text { NURSING } \\
\text { GRADUATES }\end{array}$ & $\begin{array}{l}\text { POTENTIAL } \\
\text { NUMBER OF } \\
\text { WORKING } \\
\text { YFARS OF } \\
\text { ONE } \\
\text { GRADIIATE }\end{array}$ & $\begin{array}{l}\text { TOTAL } \\
\text { POSSIBLE } \\
\text { NUMBER OF } \\
\text { WORKING- } \\
\text { YEARS OF } \\
\text { GROUP }\end{array}$ & $\begin{array}{c}\text { ACTUAL } \\
\text { NUMBER OF } \\
\text { YEARS } \\
\text { WORKED BY } \\
\text { GROUP }\end{array}$ & $\begin{array}{c}\text { PERCENTAGE } \\
\text { OF YEARS } \\
\text { WORKED IN } \\
\text { NURSING }\end{array}$ & $\begin{array}{l}\text { TOTAL YEARS } \\
\text { WORKED } \\
\text { OUTSIDE } \\
\text { NURSING }\end{array}$ \\
\hline 1962 & 6 & 15 & 90 & 42 & 46.6 & 6 \\
\hline 1963 & 5 & 14 & 70 & 35 & 50.0 & \\
\hline 1964 & 4 & 13 & 52 & 11 & 21.15 & 9 \\
\hline 1965 & 9 & 12 & 108 & 36 & 33,33 & 23 \\
\hline 1966 & 6 & 11 & 66 & 56 & 84,84 & - \\
\hline 1967 & 8 & 10 & 80 & 45 & 43,75 & \\
\hline 1968 & 10 & 9 & 90 & 60 & 66.66 & 1 \\
\hline 1969 & 6 & 8 & 48 & 20 & 41.66 & - \\
\hline 1970 & 16 & 7 & 112 & 66 & 58.92 & 5 \\
\hline 1971 & 20 & 6 & 120 & 75 & 62.50 & 5 \\
\hline 1972 & 9 & 5 & 45 & 39 & 86,66 & - \\
\hline 1973 & 10 & 4 & 40 & 33 & 82.5 & 5 \\
\hline 1974 & 8 & 3 & 24 & 15 & 62,5 & I \\
\hline 1975 & 14 & 2 & 28 & 23 & 82,14 & 2 \\
\hline 1976 & 8 & 1 & 8 & 5 & 62,5 & 1 \\
\hline TOTAL & 139 & & 981 & 551 & & 58 \\
\hline
\end{tabular}

explained that an academic qualification is often combined with a professional one. For example, various graduates have obtained an Honours degree which allows registration with the S.A. Nursing Council as a community health nurse. Several graduates have obtained more than one professional qualification. It must be noted that only students entering the course offered by the University of Natal after 1966 have been eligible for the dual registration with the S.A. Nursing Council as both general nurses and midwives. Prior to this date, students were only registered as general nurses. Thirty graduates, therefore, did not emerge as registered midwives on completion of their degree, of whom fifteen subsequently completed the one-year Diploma in Midwifery.

\section{DISCUSSION}

Information relating to the careerdevelopment of graduate nurses is vital for manpower planning in the heath sector. In view of the publicity during the last year in regard to nurses' salaries, job satisfaction and terms of employment, the finding that $90,6 \%$ of the study group's working-years has been spent within nursing; that levels of motivation have been high enough to achieve a very respectable rate of post-graduate work and even that more than half the careers followed outside nursing are careers in related fields, is rather more encouraging for the future than might have been anticipated.

\section{REFERENCE}

1. Macquire J.M. Threshold to Nursing. (Occasional Papers of Social Administration) Bell. London. 1969.
TABLE 4 EMPLOYMENT OF GRADUATES OUTSIDE

NURSING AS ON 31.12.80

TYPE OF EMPLOYMENT

Medical practitioners

Medical student

Social worker

Commerce

University lecturers in social science

Fult-time Church workers

TOTAL

TABLE 5 EMPLOYMENT OF GRADUATES WITHIN

NURSING AS ON 31.12.80

FIELD OF NURSING

General medical and surgical nursing

Community nursing

Nurse teaching

Intensive care nursing

Midwifery

Psychiatric nursing

Paediatric nursing

Operating theatre nursing

Nursing administration

TOTAL

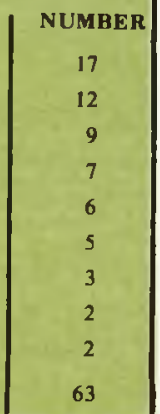

TABLE 6 PROFESSIONAL QUALIFICATIONS OBTAINED

BY GRADUATE NURSES

\section{QUALIFICATION}

Psychiatric nursing

Intensive care nursing

Community health nursing

Nursing education

Paediatric nursing

Operating theatre technique

Nursing administration

Midwifery

TOTAL

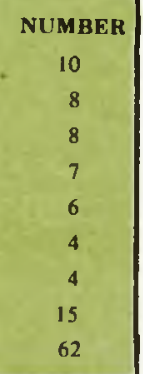

TABLE 7 POST-GRADUATE DEGREES OBTAINED BY 139 GRADUATE NURSES

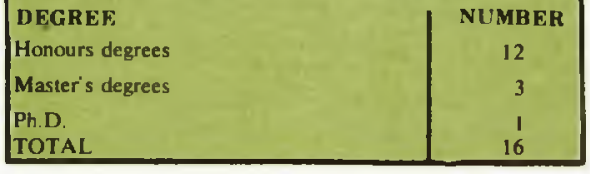

